\title{
ESTIMATION OF RISK MANAGEMENT EFFICIENCY FROM THE PERSPECTIVE OF THE STAKEHOLDERS
}

Vasilisa Makarova

National Research University Higher School of Economics, Moscow, Russia

\section{ABSTRACT}

Estimation of efficiency from the perspective of an external investor draws a high enough interest in assessing the efficiency of risk management. Since the methods risk management are nontransparent information, the carrying out of empirical research is enough complicated. However, in a number of papers the elements of the assessment of so-called "market efficiency" are traceable, among which the most common factors are: the behavior of stock prices at the moment of collapse of the market, lower average cost of capital. However, a comprehensive study on risk management efficiency of companies from the perspective of stakeholders has not yet provided. The aim of this study is to fill this gap. The purpose of this study is as follows: to identify how stakeholders assess the key factors of risk management efficiency, and to create a comprehensive approach to the implementation of this assessment with the using of statistical research techniques and methods. The object of study is the Russian real sector of economy, the subject of study is the risk management efficiency of companies. In this article author provides the results of the survey on the evaluation the risk management efficiency, processed by means of statistical analysis methods calculation of the actual ratings of Russian companies on the basis of the criteria obtained from the survey, as well as the results of the regression analysis of the impact of identified efficiency criteria of risk management on the investment attractiveness of Russian companies. In the article Russian companies are ranked based on their risk management efficiency.

\section{JEL CLASSIFICATION \& KEYWORDS}

$\begin{array}{lllllll}\text { D81 } & \text { D91 } & \text { G34 } & \text { L21 } & \text { M19 EFFICIENCY }\end{array}$ RISK MANAGEMENT RATING SCORE — INTEGRAL RATING - INVESTMENT ATTRACTIVENESS

\section{INTRODUCTION}

Corporate risk management is a relatively new scientific and practical direction of corporate governance, whose main purpose of which is to create added value for the company and to mitigate the negative effects of uncertainty. Risk management has a wide range of methods, techniques and tools, and, in the case of successful application, is able to stimulate an increase in value of the company. Nevertheless, despite its relevance, risk management reluctantly introduced to the company, this is due, primarily, to the inability to determine in advance the impact of on-going activities, as well as the lack of information on how the activities carried out would affect the attitude of stakeholders the company and the investment attractiveness in general.

Effective risk management is still the most unexplored issue in the field of corporate governance. A sufficiently large number of researchers are studying the question of what 'vmakarova@hse.ru performances management is oriented during the implementation of certain measures, but for most of them the analysis of the dynamics of one - two financial ratios of the company in the following year is quite enough. Due to the fact that risk management methods are not transparent, sufficiently high interest represents the estimation of efficiency from the perspective of stakeholders. Risk management as one of the branches of governance is focused on the creation the value for shareholders and stakeholders. Thus it is important to take into account that the basic tenets of the investment attractiveness of the company and of the concept of market efficiency, indicating that the fair value of the shares, and the value of the company in general, directly depend on the availability of information about the object of investment and the cost of its receipt.

In this article author presents the results of a study of the concept and method of estimation of risk management efficiency of the company from the perspective of external investors. The object of this article is a market component of an effective risk management, which reflects the expectations of shareholders and stakeholders on the elements of corporate governance that affect the investment attractiveness of the business.

The purpose of research: to identify the key factors of the market component of risk management efficiency using techniques of statistical methods of research and to determine the impact of these components on the investment attractiveness of the company. Prior research and the literature review.

\section{Prior research and the literature review}

The analytical report of KPMG, PWC, Ernst and Young provide evidence that the CEO's and investors are focused on the dynamics of financial performances as a result of measures of implementation or upgrading risk management. The most common performances are: EBIT, NOPAT, market value of the company and reducing the cost of loans on the open financial market. In our previous study we revealed that the revenue is the most sensitive to the risk management activities of the company in the medium term, while the other indicators (net assets, EBIT, cost of capital and capital structure) do not show significant dependence of risk management within two-three years after implementation. Theoretical research on the efficiency of risk management primarily examine the impact of risk management on company's value. The key question remains: Does the risk management increases the value of the company and, if so, how much and in what period [Larcker D.F., Richardson S.A., Tuna A.I., 2005; Smithson C., Simkins B., 2005].

Companies that implement elements of the risk management (insurance and hedging) actually performed better, comparing with other companies, but as long as ERM is a complex methodology, the effect of it, according to the 


\section{ESTIMATION OF RISK MANAGEMENT EFFICIENCY FROM THE PERSPECTIVE OF THE STAKEHOLDERS}

authors, can be determined by examining the market reaction on the presence of the risk management system in the company's governance.

In later studies [Beasley, M., Pagach, D., Warr, R., 2008] the relationship between the appointment of $\mathrm{CRO}$ and the value of shares has been tested. The appointment of CRO is interpreted as the signal that the board of directors is aware of the importance of ERM, i.e. making every effort for the development of risk management. Practical study of research rather weak confirms this hypothesis: for 120 companies (62 are the financial sector, 24 - energy, 34 other industries), where in the period of 1992-2003 CRO were appointed, no statistically significant association between this event and changes in the stock price. However, for a subset of large non-financial companies with relatively low liquidity of the market, it responds positively to the appearance in the company of Chief Risk Officer.

Hoyt R. and Liebenberg A. [2006] argue that the indicator of ERM is the existence of reports on the activities in the field of risk management, presented in the statements of the company and the media. The study focused on the insurance segment in the US in 1995-2004. Information was found for $16 \%$ of the 166 insurers, and it allow to conclude that the presence of the company's risk management system has influence on the company's value. The company's value expressed in terms of Tobin's $Q$ ratio, for which a model depends on the indicator ERM and other value drivers. The impact of ERM on firm value is statistically significant: ERM-premium averaged $3.6 \%$ of the value of the company.

In relation to public companies a comparative analysis of the share price of companies that have implemented and upgraded ERM, in moments of the stock market crash can be applied. According to various studies [Aabo T., Fraser J., Simkins B., 2005; Beasley, M., Pagach, D., Warr, R. 2008; Smithson C., Simkins B. 2005; Hoyt R., Liebenberg A. 2006], the presence of the risk management system reduce falling of stock prices on $10-30 \%$, and returns much faster to pre-crisis levels [Ragulina S., 2010].

Under present conditions, none of the submitted studies cannot be used in pure form for the Russian companies, as the information on risk management is not a subject to disclosure and companies tend to publish only data on successful interventions in this area. In addition, the Russian stock market has a fairly high volatility, low efficiency and quite impulsively responds to any event in economic and political area, and the course correction at times takes a longer period of time than in European or American market. Nevertheless, the question of how the parameter for external investors score for efficiency of risk management and whether this option remains quite relevant and important to invest in Russian business.

\section{Description of the research}

The main parameters of assessing the market component of risk management efficiency are formulated on the basis of the assumptions made in the theory of market efficiency, factors of investment attractiveness, and were obtained empirically.

Empirical research was designed to be three-fold. The first part was to conduct personal interviews with potential investors: as respondents have participated to analysts of commercial and investment banks, external experts in the field of risk management and corporate governance in general, the financial analyst, experts in the field of securities market, potential investors and investors holding several packages of securities of Russian companies. The sufficient information about the study subjects and related areas was gathered in the course of the interview. This method of data collection depends on the results of the theoretical analysis and has a high level of uncertainty in the results; however, personal interviews were chosen because of the possibility of feedback and clarifications needed to understand complex issues. A total of 17 interviews were conducted. In the process of analyzing the results of the interviews those answers were marked, that were repeated two or more times. The total list of factors that, according to respondents, demonstrate effective / ineffective system of risk management is the following:

- In relation to the main activity:

- focus only on the domestic or foreign markets;

narrow range of customers, the ability to change them;

increased receivables soft policy with debtors;

growth stocks;

an increase in accounts payable;

term cooperation with key suppliers and customers;

profitability and turnover is worse in comparison with the same companies;

- continuity of the production process;

- diversified structure of suppliers and buyers.

- In relation to financial results:

- volatility of profit / loss for several years;

- the duration of the profitable period;

the duration of success;

indicators of revenues, profits, capitalization are lower in comparison with similar companies in the market.

- In relation to the sources of business financing and capital structure:

- diversification of sources of capital;

- lack of credit history;

- low WACC or it decrease;

- violation of payment terms on loans;

- ratio of Debt / EBITDA;

- ratio of capital structure;

current ratio.

- According to the presence of external evaluations and recommendations, such as:

- the availability of claims regulatory authorities and lawsuits amounting to more than $10 \%$ of NAV;

- details of the media;

peer review and the availability of ratings.

- Directly in relation to risk management:

- relation to the key risks;

- dynamics and the absolute values of indicators: the number of accidents, claims, regulatory authorities;

- flexible, no formal approach to risk management. Risk management should not "interfere with" the work of the company, i.e. the company should not lose customers, revenues and profit due to formalities connected with him;

- cost-effective management of specific risks;

transparency of procedures; 


\section{ESTIMATION OF RISK MANAGEMENT EFFICIENCY FROM THE PERSPECTIVE OF THE STAKEHOLDERS}

- availability of specialized professionals by type of risk;

- availability of preventive procedures;

- availability of statistics and monitoring.

- Other:

- changes in management over the past 2 years;

- irregular payment of dividends.

This list of factors formed the basis of the questionnaire in which respondents were asked to classify the degree of importance of the factors for evaluating the efficiency of ERM. Questionnaire is a list of 23 issues closed type where respondents were asked to evaluate the factors of the eight-point scoring system. The questionnaire was available in the public domain, sent out to banks, financial and analytical companies, as well as in the company, carrying out financial operations in addition to the main one. Hundred questionnaires were sent out, and received 18 responses.

The analysis of results of the study revealed the insignificance of a number of factors; as a result a list of questions has been reduced to nine.

Secondary survey on a reduced list of factors yielded the following results:

- sent a questionnaire: 100 companies selected at random;

- received replies: 17;

- questionnaires containing sufficient information 17;

- consistency expert opinion on the criterion Kendall concordance is high enough - 0.716 ;

- the statistical significance of the results obtained within the significance - 0,050.

Statistical Results of the study are presented in Tables 1 and 2.

\begin{tabular}{|c|c|c|c|c|c|c|}
\hline \multicolumn{7}{|c|}{ Table 1: Descriptive Statistics } \\
\hline Index & Interpretation & $\mathrm{N}$ & Mean & Std. Deviation & Minimum & Maximum \\
\hline$k_{1}$ & \begin{tabular}{|l|}
$\begin{array}{l}\text { Diversified structure of } \\
\text { suppliers and customers }\end{array}$ \\
\end{tabular} & 17 & 4,71 & 1799 & 2 & 7 \\
\hline$k_{2}$ & $\begin{array}{l}\text { Profitability and turnover of } \\
\text { the company is better than } \\
\text { the average for the industry } \\
\text { or activity }\end{array}$ & 17 & 4,00 & 1528 & 2 & 6 \\
\hline$k_{3}$ & \begin{tabular}{|l} 
WACC is lower than the \\
industry average, or \\
decreased during the study \\
period
\end{tabular} & 17 & 3,71 & 2138 & 2 & 8 \\
\hline$k_{4}$ & $\begin{array}{l}\text { Availability of information in } \\
\text { the media }\end{array}$ & 17 & 4,14 & 1676 & 1 & 6 \\
\hline$k_{5}$ & \begin{tabular}{|l|} 
Interest coverage ratio, ICR \\
is greater than 1
\end{tabular} & 17 & 4,29 & 1380 & 3 & 7 \\
\hline$k_{6}$ & $\begin{array}{l}\text { Financial security ratio is } \\
\text { less than } 3\end{array}$ & 17 & 5,86 & 1773 & 4 & 8 \\
\hline$k_{7}$ & $\begin{array}{l}\text { The current ratio is greater } \\
\text { than } 1\end{array}$ & 17 & 5,57 & 1813 & 3 & 8 \\
\hline$k_{8}$ & $\begin{array}{|lr|}\text { The risk management policy } \\
\text { includes a a r special } \\
\text { relationship to the key risks; }\end{array}$ & 17 & 4,57 & 2370 & 2 & 8 \\
\hline$k_{9}$ & $\begin{array}{l}\text { Risk management is strict } \\
\text { compliance with the selected } \\
\text { standard }\end{array}$ & 17 & 3,14 & 1574 & 1 & 5 \\
\hline Sour & ce: Author & & & & & \\
\hline
\end{tabular}

\begin{tabular}{|l|l|}
\hline \multicolumn{2}{|l|}{ Table 2: Test Statistics } \\
\hline $\mathrm{N}$ & 17 \\
\hline Kendall's Wa & 0,716 \\
\hline Chi-Square & 11055 \\
\hline df & 5 \\
\hline Asymp. Sig. & 0,050 \\
\hline a. Kendall's Coefficient of Concordance \\
\hline Source: Author \\
\hline
\end{tabular}

www.journals.cz
In the questionnaire the importance of the criteria was estimated in the range of 1 to 8 , the maximum number of points that can get any company - 72. As a result, taking into account the distribution of responses, we obtained the following equation of market component of effective risk management:

$R=0,12^{*} k 1+0,10^{*} k 2+0,11^{*} k 3+0,10^{*} k 4+0,11^{*} k 5+$ $0,14^{*} k 6+0,12^{*} k 7+0,12^{*} k 8+0,08^{*} k 9$

The weights of the criteria are distributed in accordance with the preferences of the respondents.

In this study, we will assume that the assessment of market components of risk management has three levels: high, medium and low.

Methods for calculating the individual criteria of market components of risk management

1. Diversified structure of suppliers and customers.

This factor is a main feature of the efficiency of industry [Gort M., 1962;Yoshinara E., Sakuma A., Itami K.1979 ] and consists in:

- constant expansion of the supplier and customer base with the inclusion of new suppliers into their supply chain,

- support initiatives to diversify customers and suppliers,

- stimulation of the development and self- improvement of suppliers.

The most common methods of evaluating the structure of suppliers are ABC- and XYZ-analysis, as well as their combination. Due to fairly widespread, clarity and apparent simplicity, methods based on the criteria of Pareto-efficient, have a number of shortcomings that reduce, in my opinion, the appropriateness of the application in respect of this estimation of risk management efficiency. In this case we are talking about such disadvantages as the inability of using it in unstable conditions and companies searching for suppliers and buyers on the basis of tenders. Any new supplier or a customer enters the low value $\mathrm{C}$ or unstable $\mathrm{Z}$ category. In addition, $A B C$ and $X Y Z$ analysis designed to work in a stable environment and any crisis dramatically reduce the predictive value of the results obtained, as well as the formation of predicted values based on XYZ method according to time periods 3-5 years. In addition, data required for $A B C$ and $X Y Z$ analysis, are generally classified information that makes them unavailable for use by the user outside.

As part of this study the Herfindahl-Hirschman index (HII) would be used to assess the degree of diversification of suppliers and customers. This toolkit is designed to assess the degree of concentration and monopolization of markets, but it can be successfully used in the analysis of risk structure of providers, since the concentration of a narrow range of suppliers or customers carries a large operational risks associated with the probability of failure of the supply glut, disruption of production. Herfindahl Hirschman index shows the degree of concentration of the company on key suppliers, calculated as the sum of the squares of each firm's share of sales in the industry at the threshold value of the index in 1800. If there is only one supplier or buyer Herfindahl - Hirschman would be equal to 10000.

Herfindahl - Hirschman Ratio (HHR) shows the place, the share occupied by suppliers or buyers, owning small stakes. From the values of the Herfindahl - Hirschman coefficients and index three types of diversification of suppliers and customers are distinguished: 


\section{ESTIMATION OF RISK MANAGEMENT EFFICIENCY FROM THE PERSPECTIVE OF THE STAKEHOLDERS}

Type I - a high concentration of suppliers and risk structure: at $70 \%<\mathrm{HHR}<100 \% ; 1800<\mathrm{HHI}<10000$

Type II - medium concentration and risk structure of suppliers: at $45 \%<\mathrm{HHR}<70 \% ; 1000<\mathrm{HHI}<1800$

Type III - low concentration of suppliers: the HHR $<45 \%$; $\mathrm{HHI}<1000$

Points for inclusion in the index of efficiency are distributed as follows (Table 3):

\begin{tabular}{|l|l|l|}
\hline Table 3: The threshold values of factor \\
\hline Quality & Threshold values & Points \\
\hline High & $\mathrm{HHR}<45 \% ; \mathrm{HHI}<1000$ & 1 \\
\hline Medium & $\begin{array}{l}45 \%<\mathrm{HHR}<70 \% ; \\
1000<\mathrm{HHI}<1800\end{array}$ & 2 \\
\hline Low & $\begin{array}{l}70 \%<\mathrm{HHR}<100 \% ; \\
1800<\mathrm{HHI}<10000\end{array}$ & 3 \\
\hline \multicolumn{3}{|l}{ Source: Author }
\end{tabular}

2. Profitability and turnover of the company is better than the average for the industry or activity.

During the interview, respondents were focused on the profitability of the main activity in comparison with the industry average profitability. Profitability calculated by the formula:

\section{$E B I D T A_{\text {margin }}=E B I T D A$ revenue}

This performance shows the profitability of the company's primary income, i.e. on EBITDA. For the developed model profitability ratio is defined as the ratio of profitability to the company's profitability by economic activity. Evaluation takes place in comparison with the unit.

Points for inclusion in the index of efficiency are distributed as follows (Table 4):

\begin{tabular}{|l|l|l|}
\hline Table 4: The threshold values of factor & \\
\hline Quality & Threshold values & Points \\
\hline High & $>1,05$ & 1 \\
\hline Medium & $0,95<\mathrm{I}<1,05$ & 2 \\
\hline Low & $\mathrm{I}<0,95$ & 3 \\
\hline Source: Author & \\
\hline
\end{tabular}

3. WACC is lower than the industry average, or has decreased during the study period.

The average cost of capital, weighted with respect to funding is a relative measure of the company's capital expenditures. WACC of a company in comparison with the industry average WACC demonstrates the high cost of capital employed in relation to the average WACC by industry. Under the proposed model uses industry average indicator is compared with the private, criterion takes a positive value when the ratio is greater than one performance. WACC average value is determined according to Bloomberg.com and analytical reports of PJSC "Gazprombank".

Points for inclusion in the index of efficiency are distributed as follows (Table 5):

\begin{tabular}{|l|l|l|}
\hline \multicolumn{3}{|l|}{ Table 5: The threshold values of factor } \\
\hline Quality & Threshold values & Points \\
\hline High & $\mathrm{I}<0,95$ & 1 \\
\hline Medium & $0,95<\mathrm{I}<1,05$ & 2 \\
\hline Low & $\mathrm{I}>0,95$ & 3 \\
\hline Source: Author & \\
\hline
\end{tabular}

4. Availability of information in the media.

Does the company was subjected to inspections, whether there was negative information about the company or claim www.journals.cz from regulatory authorities. It should be noted that the absence of negative information from the media says more about the lack of checks and information, rather than about the quality of risk management. A low rating assignment talks about the company's interest in improving the quality of risk management.

Evaluation is carried out by the following algorithm: low - no information or negative, average - the availability of information on the implementation, high - availability of a press release about the successful implementation.

Points for inclusion in the index of efficiency are distributed as follows (Table 6):

\begin{tabular}{|l|l|l|}
\hline Table 6: The threshold values of factor & Points \\
\hline Quality & Threshold values & $\begin{array}{l}\text { The presence of the press } \\
\text { releases about the successful } \\
\text { implementation }\end{array}$ \\
\hline High & $\begin{array}{l}\text { The availability of information } \\
\text { on the implementation of risk } \\
\text { management }\end{array}$ & 2 \\
\hline Medium & No information or negative & 3 \\
\hline Low & \\
\hline Source: Author
\end{tabular}

5. Interest coverage ratio (ICR) is greater than 1 .

It describes the ability of organization to repay its debt obligations. The index compares the earnings before interest and taxes (EBIT) for a certain period of time (usually one year) and interest on debt for the same period. The indicator is calculated as follows:

\section{$T I E=E B I T / a n n u a l$ interest expense}

Low interest coverage ratio demonstrates the high credit burden of the organization and high probability of bankruptcy. The coefficient below 1.5 calls into question the possibility of company to service its debt. The critical factor is considered to be less than 1 (i.e. EBIT exceeds the interest payable), which means that cash flow is insufficient to pay interest to creditors.

Points for inclusion in the index of efficiency are distributed as follows (Table 7):

\begin{tabular}{|l|l|l|}
\hline Table 7: The threshold values of factor & \\
\hline Quality & Threshold values & Points \\
\hline High & $>1,05$ & 1 \\
\hline Medium & $0,95<\mathrm{I}<1,05$ & 2 \\
\hline Low & $\mathrm{I}<0,95$ & 3 \\
\hline Source: Author & \\
\hline
\end{tabular}

6. Financial security ratio is less than 3 .

This ratio is a measure of the company's ability to pay its debts, and gives investor an approximate understanding of the company's ability to repay the existing liabilities.

The ratio of debt to EBITDA shows the solvency of the company and is often used by management and investors, including the assessment of listed public companies.

The coefficient is determined by the formula:

The ratio of debt to EBITDA depends on industry characteristics, so it is often compared with the values of other companies within the industry.

Points for inclusion in the index of efficiency are distributed as follows (Table 8): 
ESTIMATION OF RISK MANAGEMENT EFFICIENCY FROM THE PERSPECTIVE OF THE STAKEHOLDERS

\begin{tabular}{|l|l|l|}
\hline Table 8: The threshold values of factor \\
\hline Quality & Threshold values & Points \\
\hline High & $<3$ & 1 \\
\hline Medium & $3<1<4$ & 2 \\
\hline Low & $4<1$ & 3 \\
\hline Source: Author & \\
\hline
\end{tabular}

7. The current ratio is greater than 1 .

The coefficient reflecting the company's ability to repay the current (short-term) liabilities due to current assets only. The higher the score - the better solvency of the company. The normal meaning is considered a value of 2 or more (in Russian regulations). A value below 1 indicates a high financial risks associated with the insolvency of the company. The value of more than 3 can indicate unsustainable capital structure.

Points for inclusion in the index of efficiency are distributed as follows (Table 9):

\begin{tabular}{|l|l|l|}
\hline Table 9: The threshold values of factor \\
\hline Quality & Threshold values & Points \\
\hline High & $>2,05$ & 1 \\
\hline Medium & $1,05<1<2,05$ & 2 \\
\hline Low & $1<1,05$ & 3 \\
\hline Source: Author & \\
\hline
\end{tabular}

8. The risk management policy includes a special relationship to the key risks.

The company carries out regular monitoring and review of the key risks, uses advanced methods of risk identification, regularly reviews the thresholds, uses special insurance programs, hedging and limiting for certain types of risk, provides regular public reports on the results of the effective work with the key types of risks, external experts are involved into the management of specific types of risks.

Points for inclusion in the index of efficiency are distributed as follows (Table 10):

\begin{tabular}{|l|l|l|}
\hline \multicolumn{3}{|l|}{ Table 10: The threshold values of factor } \\
\hline Quality & Threshold values & Points \\
\hline High & Yes & 1 \\
\hline Medium & $\begin{array}{l}\text { Yes, but the company uses a limited set of risk } \\
\text { management techniques }\end{array}$ & 2 \\
\hline Low & No information or negative & 3 \\
\hline Source: Author & \\
\hline
\end{tabular}

9. Risk management is strict compliance with the selected standard.

Risk management is implemented in strict accordance with the one of the selected standards. As the basis of risk management the company has chosen one of the modern standards for risk management $(3 ; 6 ; 11 ; 15)$ and runs in compliance with their recommendations.

Points for inclusion in the index of efficiency are distributed as follows (Table 11):

\section{Table 11: The threshold values of factor}

Quality Threshold values

High Yes, all the sections of the standard carefully studied and ${ }_{1}$

Medium Yes, but a number of sections of the standard used formally 2

Low The company formally comply with the standard

Source: Author

Practical analysis of the proposed model:

- Number of companies: 18 Company.

- The study period: 2008-2013, (the period of relatively stable development of the Russian economy).

- Indicators: EBITDA, revenue, net assets, changes in the structure of debt capital in favor of long-term debt are calculated on the basis of "organic growth".

Due to the lack of transparency the sample of companies is small. The results of calculations based on a sample of companies are presented in Table 12.

Total rating of the company was calculated according to the formula, resulting from the survey and is based on these data. The results of calculations, and also the place of a company in ranking are presented in Table 13.

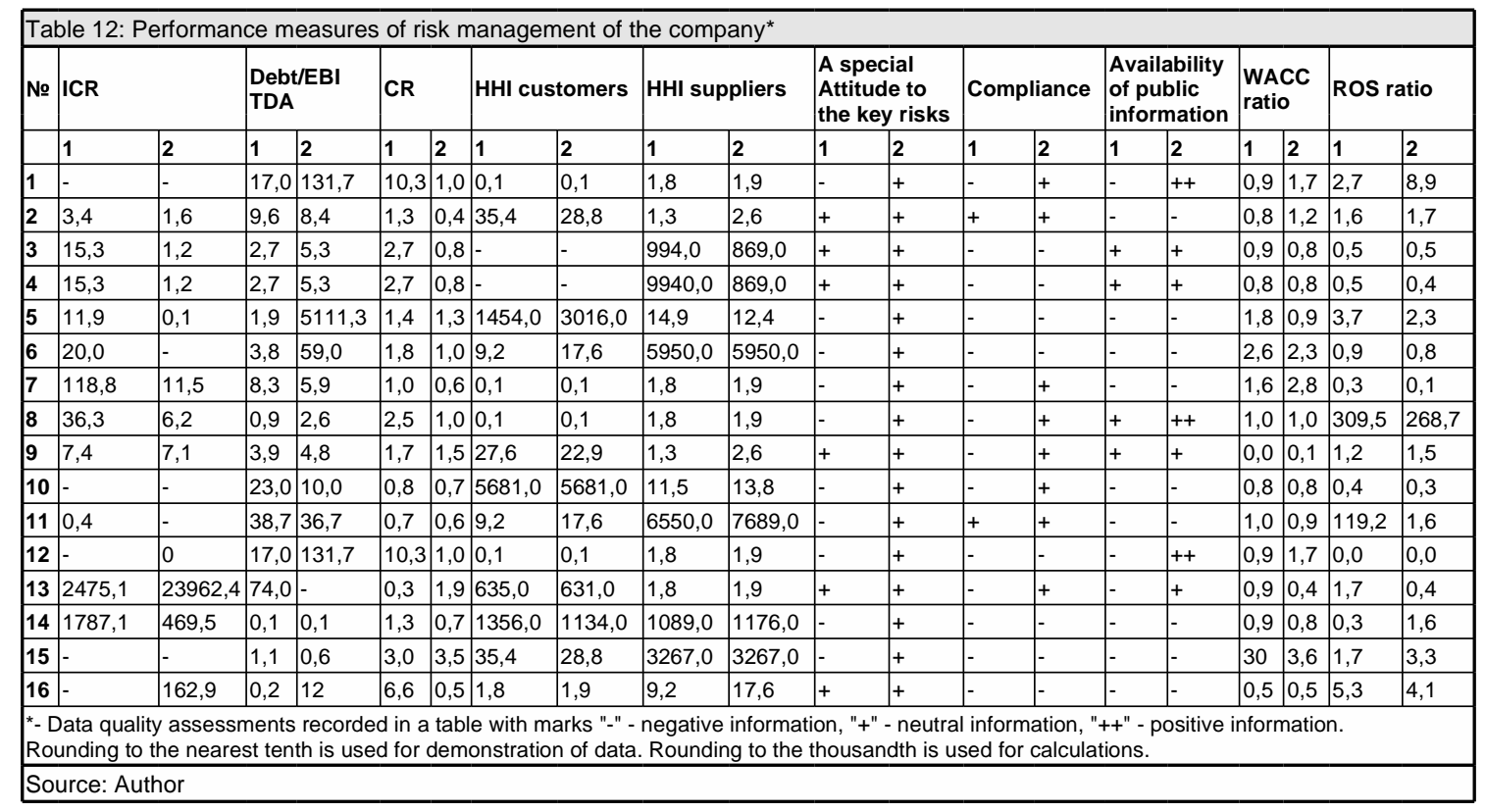




\begin{tabular}{|c|c|c|c|c|c|}
\hline \multirow[t]{3}{*}{\begin{tabular}{|l} 
№ \\
\end{tabular}} & \multicolumn{2}{|l|}{ Rating } & \multicolumn{2}{|l|}{ Place } & \multirow{2}{*}{ Change in rank } \\
\hline & \multicolumn{4}{|c|}{$\begin{array}{l}\text { Meaning before or after the measures on } \\
\text { introduction / upgrade of risk management }\end{array}$} & \\
\hline & before & after & before & after & \\
\hline 1 & 1,99 & 1,93 & 10 & 8 & improved \\
\hline 2 & 1,68 & 2,14 & 4 & 12 & worsened \\
\hline 3 & 1,72 & 2,1 & 5 & 10 & worsened \\
\hline 4 & 1,72 & 2,1 & 6 & 11 & worsened \\
\hline 5 & 2,08 & 2,34 & 12 & 14 & worsened \\
\hline 6 & 2,1 & 2,21 & 13 & 13 & not changed \\
\hline 7 & 2,42 & 2,34 & 15 & 15 & not changed \\
\hline 8 & 1,61 & 1,57 & 2 & 1 & improved \\
\hline 9 & 1,77 & 1,58 & 8 & 2 & improved \\
\hline 10 & 2,67 & 2,47 & 16 & 16 & not changed \\
\hline 11 & 2,37 & 2,03 & 14 & 9 & improved \\
\hline 12 & 1,77 & 1,79 & 7 & 7 & not changed \\
\hline 13 & 2 & 1,64 & 11 & 13 & worsened \\
\hline 14 & 1,65 & 1,72 & 3 & 4 & improved \\
\hline 15 & 1,93 & 1,73 & 9 & 5 & improved \\
\hline 16 & 1,47 & 175 & 1 & 6 & worsened \\
\hline
\end{tabular}

According to the results, it can be concluded that: the rating has not changed in $25 \%$ of companies, the rating deteriorated in 37\%, and improved in 38\% of companies.

The analysis of the data in Table 13 revealed that the overall efficiency of risk management has increased. At the same time the analysis of the companies structure in the sample on the basis of publicity has shown (within the level of significance of less than 0.05 and an acceptable level of $95 \%$ ) that improving the rankings of risk management is seen in public companies and their subsidiaries, while the downgrade is observed in non-public companies.

Further study requires quantitative analysis of marke component of risk management in relation to investment attractiveness. As mentioned above, the most problematic area of research the efficiency of elements of corporate governance is the lack of information about how the management processes are carried out within the company. Anyway, the key issue still remains what the added value is brought by the risk management. The relevance of this question is confirmed by a number of studies in the field of strategic and value-based management, where risk management is treated as "an integrated strategic process, which should be the determining factor in achieving the organization's objectives ... The effectiveness of risk management is measured by value-added companies, is due to the application of elements of risk management in the corporate management of the company. ... "[Ittner, C. D. and D. F. Larcker., 2001; COSO ERM - Integrated Framework, 2004; Davila A and Foster G., 2007]. In this case, the authors suggest to evaluate the risk management efficiency throughthe actual figures of the increment economic added value and the fundamental valueto planned. Undoubtedly, this technique allows evaluating the efficiency of ERM in the structure of corporate governance, but cannot identify a particular stake in the effectiveness brought by risk management. In order to avoid this disadvantages, we have chosen indicator EVA (economic value added) as a criterion for investment attractiveness, as well as the signal of effective risk management - the quantitative performance criteria reported by respondents during the survey and questionnaires.

www.journals.cz

\section{Description of the model parameters}

The main parameters of the model are fully consistent with the description above, except for size of the sample: in the sample presented the results of 73 companies, the expansion of the sample had taken place due to lack of the need to consider qualitative factors of risk management efficiency).

To analyze the influence of key indicators on investment attractiveness used a sample of 73 companies was used. Choosing companies belong to the real sector of the economy, and carried out measures of the implementation or upgrading of risk management in 2010-2011. The sample exclude companies - natural monopolies, federal and municipal state unitary enterprises and companies of subsidized industries. The average age of the companies more than 15 years, companies have the organizational form of a limited liability or joint-stock companies, belonging to the holding or mono-companies. The sample includes companies in the growth stage and formalization, as well as implementing projects implementation or upgrading of risk management in approximately equal proportions. Companies are divided into two groups: at the stage of growth and at stage of formalization.

Regression analysis of the impact of risk management performance criteria on the investment attractiveness of the company would be the following equation:

$y=$ const $+k_{T I E} f_{T I E}+k_{F S R} f_{F S R}+k_{C} f_{C}+k_{S} f_{S}+k_{R O S} f_{R O S}+k_{C R}$ $f_{C R}+k_{W A C C} f_{W A C C}$

where: $y$ - EVA after the implementation of risk management measures; $f_{T I E}$ - interest coverage ratio; $f_{F S R}$ - Financial security ratio; $f_{C}$ - Herfindahl - Hirschman index on customers; $f_{S}$ - Hirschman index of suppliers; $f_{R O S}$ - ROS ratio; $f_{C R}$ - current ratio; $f_{\text {WACC }}$ - WACC ratio.

On the basis of companies from the sample regression equation of the investment attractiveness of the company depending on the factors of risk management efficiency is the following:

$y=408122,3-3240,1 f_{T I E}+2962,8 f_{F S R}+10519,15 f_{S}+$ $40339,61 f_{\text {ROS }}-15406770,5 f_{C R}+3655830,38 f_{\text {WACC }}$

From the presented equation it is evident that with a probability of $95 \%$ and within the significance of less than 0.05 the investment attractiveness of the company is tolerant to $\mathrm{HHI}$ of customers and increases for companies with low TIE and current liquidity. Reduction of interest coverage ratio in conjunction with the growth WACC shows the growth of investment attractiveness for strategic partners and direct investors, and growth of the share of regular suppliers can increase investors' confidence in the smooth core business.

Practical application of the research results related to, firstly, with the creation of a criteria list, which are essential for potential investors of company. Investor, choosing a company, intended to preserve and increase their welfare commensurate with their level of risk appetite, so a preliminary assessment of risk management efficiency of the company and their impact on the investment attractiveness of the criteria are extremely important. Secondary, practical analysis of the efficiency of risk management ratings revealed that the ratings have changed for the better and the worse in equal proportions. Such dynamics indicates that the main driver of efficiency has internal reasons rather than external factors. Prolongation of modernization of the risk management processes in combination with effective debt management policy and liquidity management are able to provide consistent results, 
focused on creating value for the owners, regardless of the nature of management: conservative, moderate or aggressive.

\section{CONCLUSION}

This article presents the main results of the study in evaluation the risk management efficiency by stakeholders. Pleminary studies in this area are more focused on the reaction of the stock market value of the company on the presence of certain elements of risk management in the corporate governance. Most of them revealed rather weak effect. Therefore, in the present study goal was to identify the indicators which, according to the stakeholders, provide evaluation of risk management efficiency, as well as assess the impact of these indicators on the investment attractiveness of the company. The survey revealed more than 30 indicators, of which the most important are the following: diversified structure of suppliers and customers; profitability and turnover of the company; WACC; interest coverage ratio; financial security ratio; current ratio; availability of information in the media; quality of risk management policy. As a criterion of investment attractiveness EVA was selected,as an indicator that best relevant to attaining study objectives. The result of the study is the regression equation, which shows the dependence of the value of EVA from efficiency factors of risk management Practical analysis of a sample of 17 companies revealed that in $25 \%$ cases the efficiency has increased. These companies mainly relate to the public and carry out the annual upgrading of risk management processes, while in other companies the risk management efficiency has decreased or remained unchanged, suggesting the need for continuous improvement of risk management processes. The analysis of investment attractiveness of companies, depending on the efficiency criteria of risk management showed a high dependence of investment attractiveness on the diversification of suppliers, rational using of long-term borrowings, and great attention is paid to the financial security ratio and current ratio of a company.

\section{REFERENCES}

Aabo T., Fraser J., Simkins B. (2005). The Rise and Evolution of the Chief Risk Officer: Enterprise Risk Management at Hydro One. Journal of Applied Corporate Finance- №17 - pp. 62-75.

Beasley, M., Pagach, D., Warr, R. (2008). Information conveyed in hiring announcements of senior executives overseeing enterprisewide risk management processes. Journal of Accounting Auditing and Finance, № 23, pp. 311 .

BS 31100:2008. (2008), Retrieved September 28, 2014 http://shop.bsigroup.com/ProductDetail/?pid=000000000030191339 Badalova A.G. Panteleyev P.A. (2011). Функциональная схема системы стратегического управления риском предприятия авиационно-промышленного комплекса на основе стоимостного подхода [Funktsional'naya skhema sistemy strategicheskogo upravleniya riskom predpriyatiya aviatsionno-promyshlennogo kompleksa na osnove stoimostnogo podkhoda]. Vestnik Yurgtu (NPI). №5. $-\mathrm{S}$.21-29.

Borisov V.N. (2015). Микроэкономика [Mikroekonomika]: V 5-kh t. Obshch. red. Cheplyanskogo YU.V.. - SPb.: Ekonomicheskaya shkola,- T. 7, pp.1171.

COSO ERM - Integrated Framework (2004). Retrieved September 28, 2014, from http://www.coso.org/-ERM.htm

Damodaran A. (2007). Return on Capital (ROC), Return on Invested Capital (ROIC) and Return on Equity (ROE): Measurement and Implications, pp. 5-7. Retrieved April 15, 2015, from http://www.fep.up.pt/disciplinas/mbf922/Damodaran\%20$\% 20$ return\%20measures.pdf

Davila A and Foster G . (2005). Management accounting systems adoption decisions: evidence and performance implications from early-stage/startup companies. The Accounting Review 80(4), pp. 1039-1068.

www.journals.cz
Davila A ,Foster G (2007). Management control systems in earlystage startup companies. The Accounting Review 82(4), pp. 907937. Retrieved September 28, 2014.

Drobetz W., Schillhofer A. ,Zimmermann H. (2003). Corporate Governance and Expected Stock Returns: Evidence from Germany University of Basel; Working paper of WWZ/Department of Finance. Retrieved September 28, 2014, fromhttp://bjournal.co.uk/paper/ BJASS_14_2/BJASS_14_02_05.pdf

FERMA Risk Management Standard(2003)Retrieved September 28 2014, from http://www.ferma.eu/risk-management/standards/riskmanagement-standard

Gort M. (1962). Diversification and integration in American industry. - Prinston, Prinston University Press,- 508 p. 1962.

Hoyt R., Liebenberg A. (2006). The value of enterprise risk management: Evidence from the U.S. insurance industry. Working paper of University of Georgia.. pp 1-28.Retrieved January 06, 2015, from http://onlinelibrary.wiley.com/doi/10.1111/j.1539-6975.2011. 01413.x/abstract

Ingley C., Van der Walt N. (2005). Do Board Processes Influence Director and Board Performance? Statutory and Performance Implications. Corporate Governance: An International Review. Vol. 13. N 5. P. 632-653.

ISO 31000 - Risk Management.(2011). Retrieved September 28, 2014, from http://www.iso.org/iso/home/ standards/iso31000.htm

Ittner, C. D. Larcker D. F. (2001, December). Assessing empirical research in managerial accounting: A value-based management perspective. Journal of Accounting \& Economics - J ACCOUNT ECON, vol. 32, no. 1, pp. 349-410. Retrieved January 06, 2015, from http://www.sciencedirect.com/science/article/pii/S01654101010 0026X

Larcker D.F., Richardson S.A., Tuna A.I., (2005). How Important is Corporate Governance?, Philadelphia, PA: (Working Paper, University of Pennsylvania) University of Pennsylvania. Retrieved March 11, 2015 http://papers.ssrn.com/sol3/papers.cfm?abstract_id $=595821$

Ragulina S. (2010). ERM и стоимость заемного капитала. Влияние системы риск-менеджмента на стоимость заимствований[RM і stoimost' zayemnogo kapitala. Vliyaniye sistemy risk-menedzhmenta na stoimost' zaimstvovaniy]. \&. FINANSIST. Retrieved January 28, 2015.

Smithson C., Simkins B. (2005). Does Risk Management Add Value? A Survey of the Evidence. Journal of Applied Corporate Finance.№17. pp. 8-17.

Yoshinara E., Sakuma A., Itami K. (1979).Diversification strategy in the Japanese company. - Tokyo, Nipon Keirai, pp. 468. 